Ramona Ceciu*

\title{
TRAUMA, IDENTITY AND CULTURE: AN INTERDISCIPLINARY AND MULTICULTURAL EXPLORATION
}

Keywords: trauma; transgenerational dissemination; identity; psychology; neuroscience; cultural studies; Indian arts.

Abstract: The present article examines trauma in the multicultural context of India based on an interdisciplinary and comparative study drawing on theories from psychology, neuroscience, genetics, comparative literature, arts and cultural studies. The focus is on various forms of trauma - psychological, physical, individual, collective - and the way they shape distinct worldviews, problematic identities and conflictual selves rooted in the dialectic union of tradition and modernity that characterizes South Asian cultures in varied degrees. It is argued that these traumas get integrated into the self through a series of negotiations, emotional reverberations and transactions, yet constantly carry within them the potential of implosion/ explosion in certain situations; they lead to creative and critical subversions of social norms, to the deconstruction of language and the everyday, the emergence of new discourses, as well as to processes of restructuring the self (and psyche) through dialogical interactions with the world. These interactions between the self, being and the world develop according to two significant dimensions, namely genetic and epigenetic factors, which points to the fact that trauma has a transgenerational transmission and manifests in varied degrees and forms in different contexts of development. This paper illustrates such experiences of trauma and their impact on the human psyche by comparatively analyzing (con)texts and selves from the Indian culture and the world.

\section{Introduction}

There are various forms of trauma - psychological, physical, individual, collective - and this article examines the way they shape distinct worldviews, problematic identities and conflictual selves rooted in the dialectic union of tradition and modernity that characterizes South Asian cultures in varied degrees. In this paper I argue that such traumas get integrated into the self through a series of negotiations, emotional reverberations and (often painful) transactions, yet constantly carry within them the potential of implosion/ explosion in specific circumstances; they lead to processes of restructuring both self and identity through myriad interactions with the world. Simultaneously, they entail creative and critical subversions of social norms, the deconstruction of language and the everyday. The present work illustrates experiences of trauma chiefly caused by caste and famine by comparatively analyzing texts and selves from the Indian culture. It emphasizes the transgenerational dissemination of trauma with its multiple implications and surveys several approaches

* Jadavpur University; India. 
Trauma, Narrative, Responsibility

to trauma from India and the world, based on an interdisciplinary and comparative study drawing on theories from psychology, neuroscience, genetics, comparative literature, arts and cultural studies.

\section{Psychological and Biological Perspectives on Trauma}

The word trauma has Greek roots and means 'wound', but in Van der Kolk’s view (1987) trauma is "when an individual loses the sense of having a safe place to retreat to and process his or her emotions or experiences resulting in a feeling of helplessness" (Kahane-Nissenbaum 3). Trauma has both universal and specific aspects, which brings up the creation of parallels and comparisons between several forms of trauma, as it will be discussed in the next sections. Trauma transmission has been approached from four main perspectives: psychodynamic, sociocultural, family system, and biological (Kellermann 261). The psychodynamic theories look at the control and coping mechanisms and emotions (mostly repressed) that parents - i.e. Holocaust survivors - exhibit and their children integrate in their lives (a form of "projective identification" as D. Rowland-Klein and R. Dunlop call this behavior, 1998); on the other hand, the sociocultural perspectives focus on the transmission of norms and social learning theories, while the family system paradigm deals with the communication styles within each unit or family structure, which are mostly "closed systems” (Kahane-Nissenbaum 5-6).

Viktor Frankl, a Holocaust survivor and founder of the Third Viennese School of Psychotherapy, Logotherapy (Grk. Logos-meaning; meaning-centered psychotherapy), emphasizes the search for meaning as the most important drive in life and survival in the harshest circumstances. In his book titled Man's Search for Meaning (1992) he argues that "man is not fully conditioned and determined but rather determines himself whether he gives in to conditions or stands up to them. In other words, man is ultimately self-determining. Man does not simply exist but always decides what his existence will be, what he will become in the next moment" (133). While going through such a process, when a person finds that 'meaning' s/he becomes fulfilled; as Frankl says, “once an individual's search for a meaning is successful, it not only renders him happy but also gives him the capability to cope with suffering” (141).

There are several clinical studies on Holocaust survivors, which indicate that the impact of trauma has taken various forms: Major Depressive Disorder, Sleep Disorders, PTSD, Dissociation, “survivor's syndrome”, “survivor's guilt” (R. J. Lifton, 1967), and other disorders. In her research on the third generation Holocaust survivors, M.C. Kahane-Nissenbaum (2011) applies Viktor Frankl's existential theory and a semi-structured questionnaire called The Third Generation Questionnaire; she discovers that "among third generation survivors, pride, strength, and gratitude are as much a part of the legacy as the negative effects of the experience. The third generation appears to be reconstructing their grandparents' history, resurfacing their legacy"; moreover, the findings suggest that "rather than ruminating on the pain of their ancestors, focusing attention on their strength may result in the ability to move past the pathological symptoms" (p. vii). D. Wardi (1992) famously calls the second generation, the offspring of the survivors, "memorial candles"; these are children who 
came to assume "the burden of their parents' unresolved conflicts while at the same time serving as a link for the trauma his or her parents endured due to the war" (Kahane-Nissenbaum 1).

Several research studies have proved that there are various "biological, psychological, and philosophical after-effects of trauma (Lev-Weisel, 2007). The person becomes a victim and will likely experience a rupture in his or her daily routine (Danieli, 1998)"; on the other hand, “coping and adaptation patterns will be passed down to future generations. This process of passing down family behavioral patterns is considered to be done at both conscious and unconscious levels (Framo, 1981)” (in Kahane-Nissenbaum 4). Regarding the second generation, R. Yehuda et al. (1996) looked at the role dissociation plays in the aging survivor. "Dissociation is defined as a disruption in the usually integrated functions of consciousness, memory, identity or perception which may be sudden or gradual (American Psychiatric Association, 2000)"; since 1989, Van der Kolk and Van der Hart have theorized that trauma leads to dissociation (in Kahane-Nissenbaum 10, my emphasis).

W. Eaton, J. Sigal and M. Weinfeld (Impairment in Holocaust survivors, 1982), and other studies as well, have discovered that the first generation of survivors have suffered several physical disorders, premature aging, high mortality rates, apart from frequent nightmares, psychological disorders and socio-economic problems (Kahane-Nissenbaum12-3). The conclusions of Kahane-Nissenbaum's study point out that:

through the process of reconstructing their own legacy, some residual emotions remain while some new positive emotions have surfaced. Anger and guilt appear to have transmitted, however these emotions have taken on a new identity among this sample of third generation survivors ...; while third generation survivors continue to carry some residual remains of anger and guilt, their focus lies more heavily on their pride, commitment to Judaism, and gratitude. It might be that Frankl (1978) had a point when he stated 'those most apt to survive the camps were those oriented toward the future - toward a task, or a person, waiting for them in their future, toward a meaning to be fulfilled by the future' (63-4).

This identification of meaning in relation to a significant other or to something of substance waiting for them in future serves any traumatized persons to reorient and search for the homeostasis that can pull them off the hands of despair. As evidence shows, when children benefit from better care, as well as adequate growth environment, they can overcome easier (even in adulthood) certain patterns of thinking and feeling passed down to them genetically.

Dan Hurley reviews several scientific studies proving that traumatic experiences in our past, or in our parents' past, "leave molecular scars adhering to our DNA”. Our ancestors' experiences, good or bad, are transmitted as genetic information to the next generations. However, it must be emphasized that "the mechanisms of behavioral epigenetics underlie not only deficits and weaknesses but strengths and resiliencies, too" (2015).

Ian C. G. Weaver, Moshe Szyf, Michael Meaney and their colleagues made an experiment (Epigenetic programming by maternal behavior, 2004) and found that in mouse-pups of inattentive mothers "genes regulating the production of 
glucocorticoid receptors, which regulate sensitivity to stress hormones, were highly methylated; in the pups of conscientious moms, the genes for the glucocorticoid receptors were rarely methylated"; later, in 2008 Szyf and Meaney studied the brain of people who had committed suicide compared to the brain of people with sudden death due to other causes and discovered "excess methylation of genes in the suicide brains' hippocampus, a region critical to memory acquisition and stress response. If the suicide victims had been abused as children, they found, their brains were more methylated" (in Hurley, 2015) This means that more stress and abuses in childhood, carelessness and lack of emotional nourishment or of maternal attachment in the first years of life may lead to various disorders such as anxiety, depression, vulnerability to trauma, as well as behavioral issues in adult life. Thus there is scientific proof that "nurture alters nature", and it is understandable that the negative effects of inherited trauma may be reduced with proper nurturing.

Marianne Hirsch was the first to propose the term of "post-memory as a transgenerational transmission" in relation to collective memory and Holocaust. Several theorists support the post-memory conception because a specific approach was necessary "to study the function of traumatic experience transmission through images and stories, to establish the knowledge of experience of later generations"; this could allow one "to describe a proximal experience or indirect recall from a transgenerational point of view, in which the subjective relationship with the event is preserved” (Şimşek 21). Moreover, A. B. Baranowsky (1998) defines "transgenerational trauma transmission as 'generation after, carrying a wound without getting one"” (cited in Şimşek 24, my emphasis). Such indirect and invisible wound can create severe scars on the human psyche and life itself, with impact on one's well-being, cognitive patterns, language and behavior, thus prompting a series of interventions toward its healing.

There are various parallels and comparisons between different types of trauma, including those between Holocaust and colonization (see R. Thornton, 1987; D. E. Stannard, 1992; W. Churchill, 1997, 2004, etc.). Kirmayer, Gone and Moses (2014) analyze the historical trauma induced by colonization and the cultural oppression of the Native Americans, while emphasizing the problematic comparisons made since the 1980s (e.g. American Indian Holocaust and Survival: A Population History Since 1492, R. Thornton, 1987) between the victims of Holocaust and those of colonization. They argue that there are clear distinctions between these contexts, consequently the impact of traumas and their transmission is different. The authors point out that these historical parallels have one important function:

to recognize and valorize Indigenous peoples as victims of violent oppression at the hands of European colonizers and their regimes. Certainly there is ample evidence of violent acts of aggression, dislocation, and cultural suppression driven by ideas and policies that were racist and, in some cases, explicitly genocidal. However, much of the death and destruction visited on Indigenous peoples was not the result of a deliberate policy of extermination but a byproduct of colonial expansion and expropriation (303).

They also remark that "in addition to valorizing collective history and working for redress and reparations for past wrongs, the notion of historical trauma 
serves as a way to think about transgenerational effects” (2014: 307). It is in this perspective that such comparisons have some legitimacy.

Within the same area of trauma parallels, Tracy M. Martin notes that American Indian cultures differ to some degree, but their worldviews and values have various similarities and, generally "all aspects of their way of life have suffered devastating effects from colonization. There are a host of difficulties American Indian people struggle with today as a result of the trauma experienced by their ancestor associated with colonization and from continued racism, oppression and marginalization" (2010: 1-2). Colonization has indeed caused serious suffering, having myriad effects on the psyche and lives of the colonized people and there is no dearth of literary writings and critical works dealing with all facets of colonialism. However, at times any forms of colonization are used as an excuse for the infliction of other types of abuse and trauma, as we shall see in the next section of this paper.

\section{Trauma and Its Effects in Indian Context}

In all cultures, literature and other arts respond to social and historical events in their specific languages. In India, trauma appears in countless forms spanning centuries of social and historical events that have marked the 'Indian self' deeply, from colonization to caste discrimination, the 1943 Bengal Famine (after those of the $18^{\text {th }}$ and $19^{\text {th }}$ centuries), through the 1947 Independence and Partition - which had a strong impact upon the Indian psyche - up to the 1971 war with Pakistan and liberation of Bangladesh and other conflicts. There is an extensive Partition literature, as well as numerous writings on the Bengal Famine, refugees situation, the colonial rule, the effects of caste discrimination, the clashes between the social (people's actual lives) and the political, and other issues being recorded in their writings by authors such as Saadat Hasan Manto, Raja Rao, Khushwant Singh, Bhisham Sahni, Attia Hosain, Kamala Markandaya, Manohar Malgaonkar, Bapsi Sidhwa, Salman Rushdie, Manju Kapoor, Bhabhani Bhattacharya, and numerous others approaching trauma in its different manifestations. In many (Indian) communities, as in narratives, the individual rarely has a safe place to retreat to (as Van der Kolk has suggested) and to process his/ her feelings after any adversity.

My first illustration of trauma refers to issues pertaining to caste practices in India. European colonization has increased the emphasis on caste and various distinctions (and inequities) that were made between people, but it must be noted that such issues and practices have existed in India long before that. Indian caste system has been in place since ancient times, castes and the rules they abide by being discussed in the Law Code of Manu (Manusmriti, 2nd century CE) and other Hindu dharmasastras (scriptures and law books prescribing a pious life and possible punishments for any misdeeds of each caste). The four Hindu castes - Brahmin (priests and teachers; the highest level), Kshatriya (warriors and rulers), Vaishya (merchants and traders) and Shudra (laborers), as well as the Dalits or the outcastes constitute solid features in the people's lives and identities, imprinting the stratification and organization of Indian society. Seen from inside the culture, caste system is in a way a form of internal colonialism, where the higher castes "rule over" the lower castes, enjoying more benefits and social recognition, having specific 
customs and behaviors, demanding certain actions and labors from the lower castes and the so-called "untouchables". In any case, colonialism and caste system in Indian context are far too complex to be approached in all perspectives here.

Mahasveta Devi, one of the most powerful writers who deals with trauma in the sphere of socially aware literature, focuses primarily on the poor people and marginalized groups both in her writings and her activist work. As a case study, in her Bengali play titled "Bayen” ("The Ghoul”), Chandidasi Gangadasi is a beautiful woman, from the low-caste community of Dom, who inherits the job of burying the dead children of her village and guarding their graves after the demise of her father as the practice has run in her family line since old time. She marries Malinder Gangaputta and has with him a son, Bhagirath. In the life struggles, due to discrimination and the pain inflicted upon her by her job/ duty and people, she goes though nervous breakdown and decides to renounce her traditional line of work. Searching for solace, she tells her husband one day: "It hurts to do the job these days, the job handed down to me by my ancestors, my hands rebel, and yet I have to go on doing it. Can you tell me what I should do?” (S. Bandyopadhyay 81). While her suffering is both psychological and physical, her husband cannot empathize with her, so he has no support to offer.

It is the 'India of the villages' that chiefly concerns Mahasveta Devi; it is also one India among the myriad that represents the core of various artworks by Indian visual artists. Chitra Palekar’s film Mātī Māy (“A Grave-keeper’s Tale”, 2006) based on the story "Bayen” skillfully captures Chandi's trauma and her powerlessness in front of the collective (community) 'punitive eye' that strips her of her human rights and life, due to superstition and prejudice. As she destabilizes the 'traditional' social order by refusing to continue her family's line of work, she is branded by the community as a 'bayen', a ghoul or 'witch with an evil eye' for all human children. Precisely because she is a fearless woman with a strong individuality (which is a menace to the patriarchal order), she is turned into a ghoul or evil spirit by her own friends and family. In the sequence where the village men shout all in one voice that she is a ghoul, Chandi (played by Nandita Das) asks for the help of her husband, yet he does not have the courage and capacity to go against the collective voice and he incriminates her as well - to reinsert himself in the community and dissociate himself from her. Thus, Chandi is shown at the children cemetery surrounded by the villagers, facing her coward husband who openly declares her to be a ghoul. Her scream of pain in front of such betrayal gives rise to joy and satisfaction mixed with fear in the men and their faces exhibit this mixture with uneasiness.

Bhagirath grows to find out later that the 'bayen' (ghoul) he has heard about in people's stories is in fact his mother and for some time he resists such an idea. When in the last scene Chandidasi sacrifices her life to save the passengers of a train from the attack of robbers, that moment marks "the transformation of Chandi's life from trauma to apotheosis . . . Her son Bhagirath illustrates for the first time her subjectivity” and acknowledges Chandidasi as his mother (Ravande 205). After her death, an officer comes to the village to enquire about her relatives and caste, and she is awarded a medal of bravery. Nevertheless, her memory remains closely connected to superstition and the caste remains stuck to her identity even in death (Ceciu 227-9). 
In a different perspective, Dorothy M. Figueira (2004) questions the postcolonial critics' position of "identification with the marginalized other" and their functioning as, what Deepika Bahri calls (1995), "victims by proxy,” considering that most of the critics live "quite close to the centre" (61-63). Figueira rightly argues that "Orientalist criticism has engendered a form of fetishism wherein all current Third World ills are traced to colonial oppression"; moreover, "by reifying the history of colonialism, making it the sole source of all socio-cultural evils, postcolonial critics foreclose the possibility of interrogating and transcending the endemic social and cultural dysfunction that predates colonialism and lives on after the colonial masters have left" (65-66). Inheriting the limitations of the orientalists, "for the postcolonial elites, ... colonialism has become an opportunity, not a burden" and these critics "avoid scrutiny of time-honoured corrupt practices and nativist racism and sexism, . . . allow[ing] customary indigenous exploitation to continue” (Figueira 66). Prathama Banerjee too argues that such blaming of the colonizer for the evils of Indian society especially with regard to caste is problematic because it "really functions as a kind of disguised nationalism, which seeks to exonerate pre-colonial India from owning up to the evil of caste" (2010: 221).

Jyotsna Macwan and Suguna Ramanathan, in their paper titled "Resolving Dalit Identity: Vankars, Chamars, Valmikis", investigate the challenges faced by Gujarati Dalits (Sanskrit/ Hindi Dalit - broken/ scattered, referring to being outside the four Hindu castes) - particularly the communities of Vankars (mainly weavers), Chamars (dealing mainly trade of leather) and Valmikis ('untouchable' dirt and garbage cleaners). Through an empirical research, they show that "identity in the Dalit world is immensely complicated by perceived differences among the different Dalit castes and a reluctance to let jati [lineage] affiliation to get absorbed into a larger Dalit identity" (in Ahmad and Upadhyay 20). Paradoxically, though seen by the large segment of population as 'untouchable', the Valmikis perform (cleaning) jobs without the benefit of which the entire country would collapse to dirt and disease. Macwan and Ramanathan note this "inherent contradiction" - "they are still sweepers for all sections of the village, and a niche for them has been created in the towns as official safaikamdars" which entails a large migration of Valmikis to the urban centers; they point out that the difficulty in resolving the Dalit differences and conflicts, the problem of their continuous discrimination by dominant classes has one solution, namely "fighting for human rights against a syncretising Hindu model that privileges duty over rights" (in Ahmad and Upadhyay 2010: 24-9). However, the problem exists as long as different critics find excuses for the 'caste' practices either in colonial history or in the political needs for unitary concepts of 'nation' and 'national identity' (Ceciu 231-2).

It must be pointed out that although in contemporary times efforts have been made toward the integration of the outcaste people and tribal population closer to the center of the Indian culture, such demands, impositions and relegation have left deep marks upon the psyche of the lower castes and people continue to unconsciously transmit such psychological wounds and traumas further to their children.

In Chandi's situation, her efforts to protect her son from any trauma and social prejudice prove futile as he is witness to her pain since his inception, through his infancy and childhood due to their biological connection and attachment. On the other 
hand, the socio-cultural milieu encourages the manifestation of his parents' trauma in different forms in his own life. I would say that caste (with all its restrictions and anxieties) is no longer just a social and cultural identifier built over the historical development, it is an intense epigenetic phenomenon that causes gene polymorphisms; it is a way of living by rules that make a person curb any desire or attempt to overcome and/or improve his/her condition; it is a pattern of thinking and feeling that makes one accept his suffering and misery in the hope that 'karma would be kinder in a future life' (especially in case of lower castes and poor people); it is a mindset that is passed down on transgenerational lines and - although (post)modernity seems to try the erasure of caste from the Indian society and replace it with the distinction of "social classes" - this mindset remains deeply entrenched in the collective unconscious and finds different manifestations with every new generation.

A second illustration of trauma and its transmission focuses on the famines that have ravaged India over the years, especially the latest one happening in the 1940s. Although there are several factors that have led to its onset, the 1943-1944 famine is said to be "man-made" - which "expresses the conviction that greed and maladministration were responsible for unnecessary hunger, suffering and death. The intense political struggles of the 1940s no doubt increased the suspicion that selfish actions were to blame [...]; the evidence points to a gradual collapse of the grainmarketing system in early 1943 as the cause of famine” (Greenough 98). Moreover, the WWII had major economic impact on Bengal and India.

The famine victims' accounts, "taken together, indicate that many Bengalis at the height of the famine feared a complete collapse of Bengali culture and prosperity. This collapse involved the end of most forms of indulgence, the misappropriation of abundance, and the visible decay of vital beauty", which led to the shared vision of Bengal as a "cremation ground" instead of the old "golden Bengal"; paradoxically, the "lived experience of famine" was not touched upon by any official reports on the 1943-1944 famine, including the 1945 Report on Bengal (Greenough 139). It is this lived experience and its effects that mark deeply the human psyche up to the point of producing epigenetic changes to allow for surviving and coping with the tragedies.

This devastating famine registered varied impacts and characteristics in diverse areas. As Greenough notes, "the transition from starvation to disease in the later months of 1943 and in 1944 changed the very nature of want, which increasingly became a matter of scarce medicine" (147, my emphasis). The most affected were the economically marginal; "women were deprived in favor of men, and children in favor of adults, and such discrimination led inevitably to the break-up of households. A subpopulation of famine victims was thus generated out of the rural population of Bengal . . . and it varied according to pre-famine social and economic conditions" (Greenough 184). The exclusion of women and children from domestic subsistence by the patriarchal figure (kortās, 'masters') led to increasing prostitution rate and sales of women, as well as sales and abuse of children; the famine beggars, coming from different castes, sex and age sections, as well as both Hindu and Muslim communities, "came largely to be regarded as 'befouled', inauspicious and set apart from the rest of the society" (Greenough 223-7). As history shows, society has sacrificed some women and children (especially girls) for the sake of male privileges and welfare, especially in case of the poor segments of the population. 
Trauma, Narrative, Responsibility

Greenough argues that "the pattern of famine mortality in 1943 was more than an expression of underlying physiological tendencies within the Bengali population and that it was partly the consequence of deliberated conduct intended to assure the survival not of the fittest but of the worthiest”; thus the Bengal famine was both 'produced' by nature and culture alike (239). In this situation, prejudice and patriarchy act as chief forces driving the decisions about the right to life and the sideeffects of such decisions have spread up to the contemporary times. In any case, be it caste or gender discrimination, colonization or the violence of Partition, trauma has a transgenerational transmission and epigenetic mechanisms behind it.

\section{Conclusions}

Scientific studies prove that while social and historical traumas can be transmitted to more consecutive generations, epigenesis plays significant roles in shaping, maintaining or reducing some effects of such traumas on the successors. In the end, the genetic basis and phenotypic transformations constitute the core of human evolution; by acting upon the environment and through learning processes, human beings can alter even the genetic heritage to certain degrees. Our ancestors' traumas get passed down by genes, but the epigenetic factors and the surroundings of children while growing up play major roles in the adult life. Gene polymorphism, especially in case of hormone modulating genes, is largely hereditary and impacts the new generations' life and psyche especially if they do not benefit from proper care in the first years of development.

In conclusion, any trauma has both a transgenerational transmission and epigenetic mechanisms behind it. Children carry their forefathers' traumatic experiences and anxieties imprinted in their DNA, laying dormant until their own life conditions allow for the surfacing of those traumas in various ways. In case of India - by witnessing directly or indirectly the suffering and difficult experiences of their grand/parents (either due to caste or gender discrimination, colonization, famine or civil unrests etc.) - the new generations, in their search for meaning, have to constantly negotiate their identities, to deal with their own experiences and those physical/ psychological wounds inherited from their parents and grandparents.

\section{Works Cited:}

Ahmad, Imtiaz and Shashi Bhushan Upadhyay Eds. Dalit Assertion in Society, Literature and History. New Delhi: Orient BlackSwan, 2010. Print

Bandyopadhyay, Samik. "Introduction". Mahashweta Devi: Five Plays. Calcutta: Seagull Books, 1999. Print.

Ceciu, Ramona L. The "Empirical Self" in the Literary and Visual Language of Contemporary Indian Fiction and Visual Art. PhD Dissertation, Jadavpur University, India, 2014. 
Trauma, Narrative, Responsibility

Costa, Dora L.; Noelle Yetter and Heather DeSomer. "Intergenerational transmission of paternal trauma among US Civil War ex-POWs". PNAS/ Proceedings of the National Academy of Sciences of the United States of America, October 30, 2018, vol. 115, no. 44: pp. 11215-11220. Web. 1 May 2019. $<$ https://doi.org/10.1073/pnas.1803630115>.

Devi, Mahasveta. "Bayen” (33-45). Śreștha Galpa (Collection of short stories). Kolkata: Dey’s Publishing, 2004. Reprint 2011. Print.

Figueira, Dorothy M. "False Consciousness and the Postcolonial Subject” (60-68). Dislocations and Multiculturalisms. Ed. Jasbir Jain. Jaipur: Rawat Publications, 2004. Print.

Frankl, Viktor E. Man's search for meaning: an introduction to logotherapy, fourth ed. Boston: Beacon Press, 1992. Print.

Hurley, Dan. “Grandma’s Experiences Leave Epigenetic Mark on Your Genes”. Discover Magazine, June 25, 2015; originally in print as Trait vs. Fate, May 2013. Web. 1 May $2019<$ http://discovermagazine.com/2013/may/13grandmas-experiences-leave-epigenetic-mark-on-your-genes $>$.

Kahane-Nissenbaum, Melissa C. "Exploring Intergenerational Transmission of Trauma in Third Generation Holocaust Survivors”. Doctorate in Social Work (DSW) Dissertations, 16, 2011. Web. 2 May 2019. $<$ http://repository.upenn.edu/edissertations_sp2/16>.

Kellermann, Natan P. F. "Transmission of Holocaust trauma - An integrative view”. Israel Journal of Psychiatry, 64(3), Fall (2001): 256-267.

Kirmayer, Laurence J., Joseph P. Gone and Joshua Moses. "Rethinking Historical Trauma”. Transcultural Psychiatry, Vol. 51(3), (2014): 299-319. Web. 24 July 2019. DOI: 10.1177/1363461514536358.

Martin, Tracy M. Trauma Among Native American Populations: What Counselors Should Know. Dissertation, Winona State University, Spring, 2010. Web. 2 May 2019.

Palekar Chitra. Dir. Mātī Māy (“A grave-keeper’s Tale”). Mumbai, India: DNYA Films, 2008.

Greenough, Paul R. Prosperity and misery in modern Bengal. The Famine of 19431944. New York: Oxford University Press, 1982. Print.

Ravande, Durgesh. "From Vocation to Apotheosis: A Psycho-Feminist Study of Mahasweta Devi's Bayen” (202-205). Proceedings of National Seminar on Postmodern Literary Theory and Literature, Jan. 27-28, 2012, Nanded (India).

Şimşek, Anjelika Huseyinzade. Post-Memory: Family as A Space of Historical Trauma Transmission (21-34). In Bora Erdağı ed. Current Debates in Philosophy and Psychology, Vol. 11., December. London \& Istanbul: IJOPEC Publication, 2017. Web. 1 June 2019.

Yehuda, Rachel; Guiqing Cai, Julia A. Golier, Casey Sarapas, Sandro Galea, Marcus Ising, Theo Rein, James Schmeidler, Bertram Müller-Myhsok, Florian Holsboer, and Joseph D. Buxbaum. "Gene Expression Patterns Associated with Posttraumatic Stress Disorder Following Exposure to the World Trade Center Attacks”. Biological Psychiatry, 2009. 